\title{
Chemical Composition of Peloid from Lake Khyargas
}

\author{
Bayaraa Batnasan*, Ganzaya Gankhurel, Dolmaa Gania** \\ Institute of Chemistry and Chemical Technology, Mongolian Academy of Sciences, \\ $4^{\text {th }}$ Building of MAS, Ulaanbaatar 13330, Mongolia \\ *Corresponding author.Email: bayaraa_b@mas.ac.mn \\ ** deceased
}

\begin{abstract}
The purpose of the study was to determine chemical and organic matter compositions of peloid from Lake Khyargas in Uvs province by chemical and instrumental methods, including X-ray, ICP-OES, and GS/MS. Based on our results, it was identified that the peloid from Lake Khyargas belongs to hydrogen sulfide mud. The content of microelements ranged from $0.5-480 \mathrm{ppm}$. The peloid contains humic substance $18.08 \%$, lipid $6.56 \%$, and carbohydrate $15.95 \%$ in total organic matter (TOM). In addition, organic matter extracted by non-polar and polar solvents counts for $1.83 \%$ of TOM. The organic extracts were analyzed by gas chromatography-mass spectrometry (GC/MS) and identified 110 organic compounds in peloid from Lake Khyargas. There were compounds hydrocarbons and their derivatives (16.27\%), carboxylic acid (12.94\%), dialkyl phthalate (6.52\%), element sulfur $(4.53 \%)$, alcohol $(17.65 \%)$, halogen bearing hydrocarbons $(2.26 \%)$, nitrogen-containing compound $(12.19 \%)$, cyclic hydrocarbons $(0.41 \%)$, steroids $(0.49 \%)$, and ketone $(14.52 \%)$.
\end{abstract}

\section{Keywords: Peloid, Organic Matter, Humic Substance, Lipid, Carbohydrate}

\section{INTRODUCTION}

Peloid is a mineral resource with local and geological characteristics. It is a sticky, flexible, great importance natural product with a wide range of elements, minerals and organic substances, and many microorganisms. In general, the application of peloids on the body including the different part of the body or the whole body is for treatment related to musclebone-skin pathologies and for wellness and relaxation [1-3].

Mongolia is a rich source of peloids. In Mongolia, natural peloids used in pelotherapy are abundant, and people used them in traditional medicine to treat pains. However, the exact composition of the peloid is less studied. Since 2000, our research team at the Institute of Chemistry and Chemical Technology of the Mongolian Academy of Sciences (MAS) has studied physicochemical properties and organic compounds of peloids from 48 lakes in Mongolia. Peloids from Western Mongolia have been used for therapeutic and aesthetic purposes since long ago. This has not been researched thoroughly until now. Our research, in contrast, is unique that we study the peloids from Western Mongolia for the first time. The main objective of this study was to identify which type the peloid from Lake Khyargas belongs to and determine the chemical composition and some organic compounds of natural peloid from the Western region of Mongolia. The result of this research is expected to increase local spacenters' opportunities to engage in entrepreneurship of medical tourism uses natural resources.

\section{EXPERIMENTAL}

\subsection{Sampling Area and Material}

Lake Khyargas (geographic coordinates $49^{\circ} 10^{\prime}$ $\mathrm{N}, 93^{\circ} 20^{\prime} \mathrm{E}$ ) is located in Zavkhan soum of Uvs province in the Western region of Mongolia. Lake Khyargas is at an altitude of $1024 \mathrm{~m}$ and has a surface area of about 1406.8 ha with a length of 75 $\mathrm{km}$, a width of $31 \mathrm{~km}$, an average depth of $47 \mathrm{~m}$, and a volume of $66034 \mathrm{~m}^{3}$ [4]. Samples were collected from 2 locations northwest and south of Lake Khyargas. 


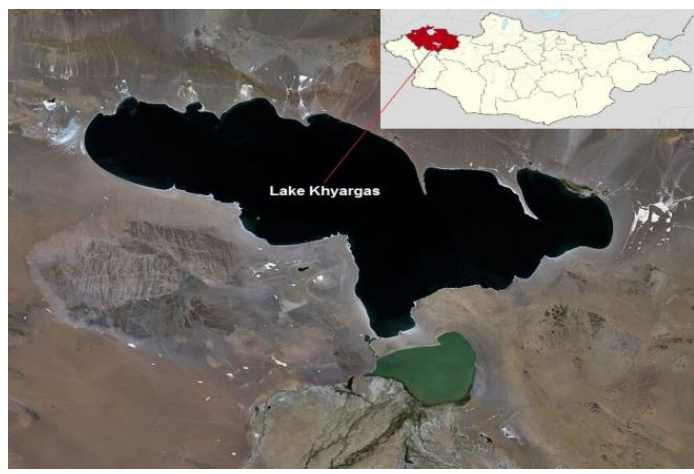

Figure 1. The study area of Lake Khyargas, Zavkhan soum, Uvs Province

\subsection{General Characteristics}

We used glass bottles for taking and preparing samples according to the MNS 5848:2008 standard [5]. The general characteristics of medical muds were determined by national standard MNS 5849:2008 [6] separately, on the samples from both locations.

\subsection{Mineralogical and Chemical Composition}

The organic components, mineralogical and chemical compositions were determined by preparing a mixture (1:1) of two samples.

The mineralogical composition of the peloid mud was determined at the Institute of Physics and Technology, MAS via X-ray diffraction (XRD) using a SHIMADZU Maxima-X XRD-7001 X-ray instrument with $\mathrm{Cu} \mathrm{K} \alpha$ radiation. Data were collected at a voltage of $40 \mathrm{kV}$ and a current of $30 \mathrm{~mA}$ in the range from 10 to $80^{\circ} 2 \theta$ with a speed of $0.02^{\circ} \mathrm{s}^{-1} 2$ $\theta / \mathrm{min}$.

The chemical composition of the peloid was determined by Inductively Coupled Plasma-Optical Emission Spectroscopy (ICP-OES) using the Agilent ICP-OES 5110 equipment. The analysis was carried out at the ALS geochemistry laboratory of Mongolia.

\subsection{Determination of Organic Components}

The concentration of total organic carbon (TOC) was analyzed by the Tyurin method. The concentration of total organic matter (TOM) was evaluated by Equation (1).

$T O M=T O C \cdot 1.72$

The yield of lipid and humic substances were determined by MNS 5443:2005 and MNS 5442:2005 standards $[7,8]$, respectively. The yield of free or extractable organic matters in peloid was determined as follows: peloid was washed several times by distilled water to remove salts, and dried, then extracted sequentially with hexane, chloroform, acetone, and a mixture of ethanol:benzene (1:9) in the Soxhlet apparatus. The solvents were evaporated by a rotary vacuum evaporator [9]. The extracted fractions were mixed and dissolved in chloroform. Dissolved organic matter (DOM) in chloroform was analyzed using gas chromatography-mass spectrometry (GC/MS).

\subsection{Gas Chromatography-Mass Spectrometry Analysis (GC-MS):}

Gas Chromatography-Mass Spectrometry was performed using Thermo Scientific GC (Trace 1310) -MS (TSQ 8000). The GC-MS was fitted with a 30 $\mathrm{m}$ Agilent fused capillary column, DB-5 ms 0.25 $\mathrm{mm}, 0.25 \mathrm{~mm}$ Film-initial temp $50^{\circ} \mathrm{C}$ held for $1 \mathrm{~min}$, then programmed at $8^{\circ} \mathrm{C} / \mathrm{min}$ ramp to $300^{\circ} \mathrm{C}$, the isothermal temperature was held for $30 \mathrm{~min}$. The injection port temperature was $250^{\circ} \mathrm{C}$, and $1 \mu \mathrm{L}$ volume was injected into a splitless mode. Helium was used as a carrier gas at a constant flow of 1.5 $\mathrm{mL} / \mathrm{min}$, head pressure 9.10 psi. The mass spectrometer was operated in an electron ionization mode with ion source temperature at $250^{\circ} \mathrm{C}$. The organic compounds were identified by databases NIST Mass Spectral Search Program.

\section{RESULT AND DISCUSSION}

\subsection{General Characterization of Peloid from Lake Khyargas}

We determined the general characteristics of peloid at two sites of Lake Khyargas are shown in Table 1.

Table 1. General characteristics of peloid from Lake Khyargas.

\begin{tabular}{|c|c|c|c|}
\hline \multirow[t]{2}{*}{ General characteristics } & \multicolumn{2}{|c|}{$\begin{array}{l}\text { Peloid of Lake } \\
\text { Khyargas }\end{array}$} & \multirow{2}{*}{$\begin{array}{l}\text { Hydrogen } \\
\text { sulfide } \\
\text { sticky mud }\end{array}$} \\
\hline & South & Northwest & \\
\hline Color & $\begin{array}{l}\text { Dark } \\
\text { gray }\end{array}$ & $\begin{array}{l}\text { Dark } \\
\text { gray }\end{array}$ & Dark gray \\
\hline pH & 8 & 8 & $7.0-9.7$ \\
\hline Moisture, \% & 30.82 & 27.34 & $40-61$ \\
\hline Density, $\mathrm{g} / \mathrm{cm}^{3}$ & 1.75 & 1.79 & $1.1-1.6$ \\
\hline $\begin{array}{l}\text { Particles }>0.25 \mathrm{~mm} \\
\text { diameter, \% }\end{array}$ & 7.35 & 9.92 & $2-3$ \\
\hline Hydrogen sulfide, \% & 0.306 & 0.327 & $0.05-0.5$ \\
\hline $\begin{array}{l}\text { Total organic carbon } \\
\text { (TOC), \% }\end{array}$ & 1.43 & 1.00 & $1-15$ \\
\hline $\begin{array}{l}\text { Heat capacity, cal/g } \\
\text { grad }\end{array}$ & 0.72 & 0.51 & $0.4-0.8$ \\
\hline
\end{tabular}


The investigated peloids were a sticky mass of dark gray color with a light smell of hydrogen sulfide. The moisture amount of $100 \mathrm{~g}$ natural clay was $27.34-30.82 \%$.

$\mathrm{H}_{2} \mathrm{~S}$ possesses important physiological and pharmacological functions in the regulation of blood pressure [10], and its content varied between 0.03 and $0.89 \%$ in dry peloids. The studied peloid content of $\mathrm{H}_{2} \mathrm{~S}$ was $0.306-0.327 \%$. The peloid is not suitable to use directly for treatment because of its high content of mechanical admixtures (7.35-9.92\%) with a grain size greater than $0.25 \mathrm{~mm}$. Therefore, after eliminating mechanical admixtures, it may be possible to use for treatment purpose. According to the general characteristics of medical muds by MNS 5849:2008 [6], we classified Lake Khyargas peloid as a hydrogen sulfide sticky mud based on mud's properties.

\subsection{Mineral and Element Composition in Peloid from Lake Khyargas}

The mineral composition results are shown in Figure 2. According to the XRD analysis, the mineral composition of Khyargas peloid consists of quartz $(52.21 \%)$, albite $(21 \%)$, kaolinite $(16.34 \%)$, and calcite $(10.45 \%)$. This study has shown that the peloid has belonged to the poly-mineral group.

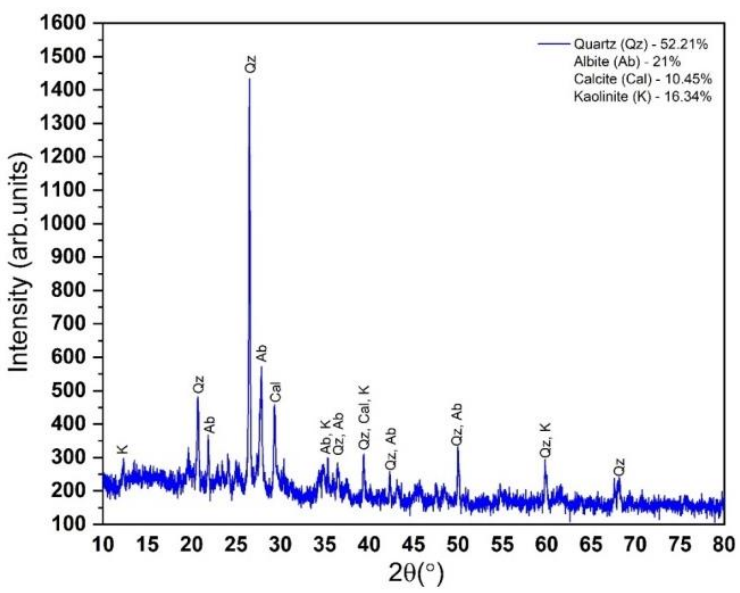

Figure 2. XRD pattern of peloid from Lake Khyargas

The content of trace elements in the soils and healing mud is attracting the interest of researchers in the field. Besides, it has been reported [11] that the therapeutic effect of peloids is determined by their elemental composition.

Contents of major and trace elements including $\mathrm{Si}, \mathrm{Al}, \mathrm{Fe}, \mathrm{Mg}, \mathrm{Cr}, \mathrm{Co}, \mathrm{V}, \mathrm{Zn}, \mathrm{Ni}, \mathrm{Pb}, \mathrm{La}, \mathrm{Ce}, \mathrm{U}, \mathrm{W}$, Th, As, and Mo were compared with the ranges of the continental crust [12], as shown in Table 2. The studied peloid have a slightly elevated content of $\mathrm{Zn}$ (95 ppm), Th (20 ppm), W (10 ppm), and Ba (480 ppm) compared to continental crust. Content of other elements was generally lower than continental crust. The major and trace elements of the peloid are related to their mineralogical composition.

Table 2. Chemical composition of peloid

\begin{tabular}{|c|c|c|c|}
\hline \multicolumn{2}{|c|}{ Elements } & $\begin{array}{c}\text { Peloid of Lake } \\
\text { Khyargas }\end{array}$ & $\begin{array}{l}\text { Continental } \\
\text { crust [12] }\end{array}$ \\
\hline \multirow{8}{*}{ 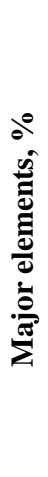 } & $\mathrm{SiO}_{2}$ & 57.7 & 60.6 \\
\hline & $\mathrm{Al}_{2} \mathrm{O}_{3}$ & 13.6 & 15.9 \\
\hline & $\mathrm{Fe}_{2} \mathrm{O}_{3}$ & 11.8 & 6.71 \\
\hline & $\mathrm{MgO}$ & 2.7 & 4.66 \\
\hline & $\mathrm{CaO}$ & 6.74 & 6.41 \\
\hline & $\mathrm{Na}_{2} \mathrm{O}$ & 4.1 & 3.07 \\
\hline & $\mathrm{K}_{2} \mathrm{O}$ & 5.54 & 1.81 \\
\hline & $\mathrm{P}_{2} \mathrm{O}_{5}$ & 0.33 & 0.13 \\
\hline \multirow{23}{*}{ 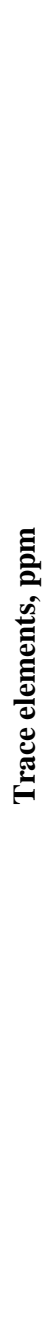 } & $\mathrm{Ba}$ & 480 & 456 \\
\hline & $\mathrm{Be}$ & 2.8 & 1.9 \\
\hline & $\mathrm{Bi}$ & 2 & 0.18 \\
\hline & $\mathrm{Cd}$ & 0.5 & 0.08 \\
\hline & Co & 15 & 26.6 \\
\hline & $\mathrm{Cr}$ & 66 & 135 \\
\hline & $\mathrm{Cu}$ & 37 & 27 \\
\hline & $\mathrm{Ga}$ & 20 & 16 \\
\hline & $\mathrm{La}$ & 40 & 20 \\
\hline & Mo & 3 & 0.8 \\
\hline & $\mathrm{Ni}$ & 41 & 59 \\
\hline & $\mathrm{Pb}$ & 19 & 11 \\
\hline & $\mathrm{Sb}$ & 5 & 0.2 \\
\hline & $\mathrm{Sc}$ & 15 & 0.08 \\
\hline & $\mathrm{Sr}$ & 340 & 320 \\
\hline & Th & 20 & 5.6 \\
\hline & U & 10 & 1.3 \\
\hline & V & 108 & 138 \\
\hline & W & 10 & 1 \\
\hline & $\mathrm{Zn}$ & 95 & 72 \\
\hline & As & 11 & 14 \\
\hline & $\mathrm{Ag}$ & 0.5 & 0.102 \\
\hline & $\mathrm{S}$ & 600 & 611 \\
\hline
\end{tabular}


The content of Th has increased due to the sand of monazite and zircon [13]. Principal mineral-forming elements such as $\mathrm{MgO}(2.7 \%), \mathrm{Al}_{2} \mathrm{O}_{3}(13.6 \%), \mathrm{Na}_{2} \mathrm{O}$ (4.1\%), and $\mathrm{CaO}(6.74 \%)$ were identified in peloid from Lake Khyargas. This elemental analysis confirmed that peloids are primary sediment.

Peloid contains some biologically active substances such as humic substances, lipid, and carbohydrates [14]. The organic matter of peloid is unique in its composition and quantity because peloid formation depends on many different factors such as the physicochemical and geological processes in peloid, as well as geographical location, and climate, the origin of lakes. The yield of total organic carbon in a mixture $(1: 1)$ of two samples was $1.64 \%$. TOM content, as estimated from TOC content, was $2.82 \%$ in dry weight. TOM comprises a humic substance of $18.08 \%$, lipid $6.56 \%$, and carbohydrate $15.95 \%$.

Organic matters of peloid influence their physical, chemical properties, and biological activity. There are free or extractable and also mineral-associated organic matter e.g., silicate, carbonate, and sulfide minerals in peloid [15]. The free organic component extracted from salt-free dried peloid, are listed in Table 3. The free organic matter was more extracted by acetone than other solvents. This result indicates that free organic matter contained polar organic compounds.
Chloroform-dissoluble fraction, from total extracts of sequential extraction by various organic solvents, was analyzed using the GC/MS method. We were able to identify so far 110 individual organic compounds in the peloid organic extracts. The GS/MS chromatogram and compounds identified are shown in Figure 3 and Table 4.

Table 3. Free organic components of peloid

\begin{tabular}{|l|l|l|l|l|}
\hline \multicolumn{2}{|l|}{ Solvents } & $\begin{array}{l}\text { Extraction } \\
\text { time, hour }\end{array}$ & $\begin{array}{l}\text { Yield, mg } \\
\text { (In dry } \\
\text { mud) }\end{array}$ & $\begin{array}{l}\text { Yield,\% } \\
\text { (In } \\
\text { TOM) }\end{array}$ \\
\hline a & Hexane & 9 & 75 & 0.26 \\
\hline b & Chloroform & 16 & 31 & 0.11 \\
\hline c & Acetone & 32 & 230 & 0.82 \\
\hline d & $\begin{array}{l}\text { Ethanol: } \\
\text { Benzene } \\
/ 1: 9 /\end{array}$ & 30 & 18 & 0.64 \\
\hline & Amount & 107 & 354 & 1.83 \\
\hline
\end{tabular}

Dissoluble organic matter (DOM) extract from Khyargaspeloid contained alkanes $\mathrm{C}_{17}-\mathrm{C}_{27} 7.54 \%$, $\mathrm{C}_{29}-\mathrm{C}_{44} 2.46 \%$, alkenes with $\mathrm{C}_{26} 0.54 \%$, and $\mathrm{C}_{35}$ $5.73 \%$, dialkylphthalate $6.52 \%$, element sulfur $4.53 \%$, alcohol $17.65 \%$, halogen bearing hydrocarbons $2.26 \%$, nitrogen-containing compound $12.19 \%$, cyclic hydrocarbons $0.41 \%$, steroids $0.49 \%$, and ketone $14.52 \%$.

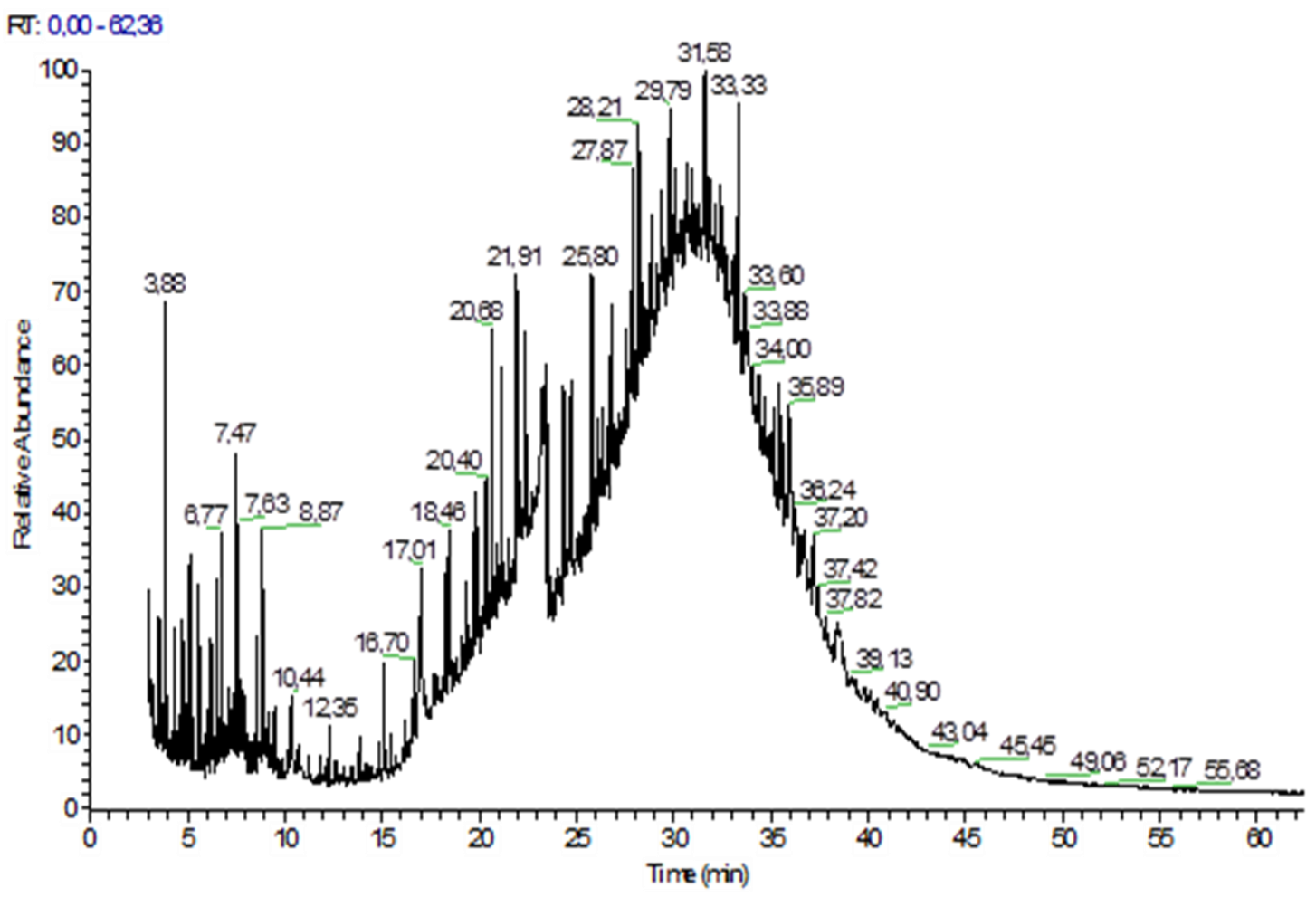

Figure 3. Chromatogram of DOM isolated from peloid in Lake Khyargas 
Table 4. The chemical composition of DOM of peloid

\begin{tabular}{|c|c|c|c|c|c|c|}
\hline \multicolumn{2}{|l|}{ Hydrocarbons } & \multicolumn{2}{|c|}{ Carboxylic acid and their ether } & \multirow{2}{*}{$\begin{array}{l}\text { Element } \\
\text { sulfur }\end{array}$} & \multirow[b]{2}{*}{ Alcohol } & \multirow[b]{2}{*}{ Other } \\
\hline$\left(\mathrm{C}_{\mathrm{n}} \mathrm{H}_{2 \mathrm{n}+2}\right)$ & $\left(\mathrm{C}_{\mathrm{n}} \mathrm{H}_{2 \mathrm{n}}\right)$ & $\begin{array}{l}\mathrm{RC}(\mathrm{O}) \mathrm{OR}^{1} \\
\left(\mathrm{R} ; \mathrm{R}^{1}\right)\end{array}$ & $\begin{array}{l}\mathrm{C}_{6} \mathrm{H}_{4}(\mathrm{COO})_{2} \mathrm{RR}^{1} \\
\left(\mathrm{R} ; \mathrm{R}^{1}\right)\end{array}$ & & & \\
\hline $\begin{array}{l}7.54\left(\mathrm{C}_{17}-\mathrm{C}_{27}\right) \\
2.46\left(\mathrm{C}_{29}-\mathrm{C}_{44}\right) \\
\mathbf{1 0 . 0}\end{array}$ & $\begin{array}{l}0.54 \mathrm{C}_{26} \\
5.73 \mathrm{C}_{35}\end{array}$ & $\begin{array}{l}0.56\left(\mathrm{C}_{5} \mathrm{H}_{10} ; \mathrm{H}\right) \\
2.04\left(\mathrm{C}_{15} \mathrm{H}_{29} ; \mathrm{H}\right) \\
0.13\left(\mathrm{C}_{19} \mathrm{H}_{37} ; \mathrm{H}\right) \\
1.2\left(\mathrm{C}_{15} \mathrm{H}_{29} ; \mathrm{H}\right) \\
0.37\left(\mathrm{C}_{16} \mathrm{H}_{33} ; \mathrm{H}\right) \\
0.64\left(\mathrm{C}_{15} \mathrm{H}_{31} ; \mathrm{C}_{2} \mathrm{H}_{5}\right) \\
1.48\left(\mathrm{C}_{17} \mathrm{H}_{33} ; \mathrm{C}_{18} \mathrm{H}_{37}\right) \\
\mathbf{6 . 4 2}\end{array}$ & $\begin{array}{l}0.15\left(\mathrm{CH}_{3} ; \mathrm{CH}_{3}\right) \\
3.83\left(\mathrm{C}_{4} \mathrm{H}_{9} ; \mathrm{C}_{4} \mathrm{H}_{9}\right) \\
2.54\left(\mathrm{C}_{8} \mathrm{H}_{17} ; \mathrm{C}_{8} \mathrm{H}_{17}\right)\end{array}$ & 4.53 & 17.65 & $\begin{array}{l}2.26^{1} \\
12.19^{2} \\
0.41^{3} \\
14.52^{4} \\
0.49^{5} \\
1.79^{6} \\
\\
\mathbf{3 1 . 6 6}\end{array}$ \\
\hline
\end{tabular}

Note: ${ }^{1}$ halogen bearing hydrocarbons, ${ }^{2}$ nitrogen-containing compounds, ${ }^{3}$ cyclic hydrocarbons, ${ }^{4}$ ketone, ${ }^{5}$ steroid and ${ }^{6}$ unknown.

\section{CONCLUSION}

The physicochemical characteristics and organic matters of peloid from Lake Khyargas in Mongolia were investigated. The studied peloids were a sticky mass of dark gray color with a light smell of hydrogen sulfide, had a density of $1.75-1.79 \mathrm{~g} / \mathrm{cm}^{3}$, the moisture of $27.34-30.82 \%, \mathrm{H}_{2} \mathrm{~S}$ of $0.306-0.327 \%$, Total organic carbon (TOC) of $1.00-1.43 \%$, respectively. This peloid belongs to the hydrosulfide sticky mud according to general characteristics of medical muds by MNS 5849:2008. The total organic matter (TOM) was $2.82 \%$ in peloid dry weight. Moreover, TOM contains humic substance $18.08 \%$, lipid $6.56 \%$, carbohydrate $15.95 \%$, and extractable free organic matter $1.83 \%$, respectively. Dissolved organic matter (DOM) in chloroform was analyzed using the gas chromatography-mass spectrometry (GC/MS) method, and then 110 compounds were identified in the peloid. The DOM composition dominated saturated and unsaturated hydrocarbons with 17-44 carbon atoms, alcohol, and nitrogencontaining compound.

\section{REFERENCES}

[1] Veniale F., Bettero A., Jobstraibizer P.G., Setti M., (2007) Thermal muds: Perspectives of innovations, Applied Clay Science. Vol. 36, 141-47. DOI: 10.1016/j.clay.2006.04.013

[2] Carretero M.I., Pozo M., Martin-Rubi J.A., Pozo E., Maraver F., (2010) Mobility of elements in interaction between artificial sweat and peloids used in Spanish spas, Appl Clay Science, Vol. 48, 506-15. DOI: 10.1016/j.clay.2010.02.016

[3] Quintela A., Terroso D., Ferreira E., Rocha F., (2012) Certification and quality criteria of peloids used for therapeutic purposes, Clay
Miner, Vol. 47, 441-51. DOI: 10.1180/claymin.2012.047.4.04

[4] Tserensodnom J., (2000) The catalogue of Mongolian lakes. 1st ed., Ulaanbaatar, 61 (in Mongolian). 85.

[5] Dolmaa G., Tserenpil Sh., Nambar B., (2008) Therapeutic mud: The classification and the general requirement for sampling and their storages. MNS 5848:2008 (in Mongolian)

[6] Dolmaa G., Tserenpil Sh., Ganzaya G., Enkhbadral U., Bayarmaa B., Ugtakhbayar O., (2008) Chemical and physical methods for determining the characteristics of therapeutic mud. MNS 5849:2008 (in Mongolian).

[7] Method of determination total lipid contents in medical mud, Mongolia. MNS 5443-2005.

[8] Method of determination of humic compounds content in medical mud, Mongolia. MNS 54422005.

[9] Gankhurel, G., Byambajav, N., Batnasan, B., \& Gania, D., (2021) The general characteristics and organic matters of therapeutic mud from Lake Noot (Mongolia). Mongolian Journal of Chemistry, Vol. 22(48), DOI: 10.5564/mjc.v22i48.1644

[10] Rui W., (2002) Two's company, three's a crowd: can $\mathrm{H} 2 \mathrm{~S}$ be the third endogenous gaseous transmitter. The FASEB Journal, Vol. $16,1792-1798$

[11] Gomes C.S.F., Silva J.B.P., (2007) Minerals and clay minerals in medical geology, Applied Clay Science, Vol. 36, 4-21. DOI: 10.1016/j.clay.2006.08.006

[12] Rudnick R.L., Gao S., (2003) The Composition of the Continental Crust. Treatise on 
Geochemistry, Vol. 3, 1-64. DOI: 10.1016/b008-043751-6/03016-4

[13] Chertko N.K., Chertko E.N., (2008) Geochemistry and Ecology of chemical elements, Minsk, Publishing Center, 131-132.

[14] Dolmaa G., Tserenpil Sh., Ugtakhbayar O., Chuvashev Yu.A., Voronko M.G., (2004) Organic substances of silicate and sulfide in Mongolian some deposits peloid, ICCT, MAS, annual report, Vol.5, 11.

[15] Dolmaa G., (2012) Peloid is magnificent product of nature, Ulaanbaatar, Khukhsudar printing, 132. (in Mongolian) 